\title{
Freedom, Happiness, and the Communion of Life ${ }^{1}$
}

\section{Tsoncho Tsonchev, McGill University}

\begin{abstract}
The first part of this paper discusses the question of freedom and happiness through the prism of Dostoyevsky's Story of the Grand Inquisitor and Evgenyi Zamyatin's dystopia We. It argues that the goal of human life is not happiness but freedom, and that materialistic utilitarianism and rationalism do not oppose totalitarianism. The second part of the paper shows, through the philosophy of Nikolai Berdyaev, that freedom is both personalistic and communitarian and that death and separation in our lives cannot destroy life and the meaning of life. According to Berdyaev's eschatological vision, there is no individual salvation; life is eternal and essentially communal. The argument of this paper could be described as theologia crucis.
\end{abstract}

For whatever is born of God overcomes the world; and this is the victory that has overcome the world-our faith. (1 John 5:4)

Keywords: Nikolai Berdyaev, Freedom and Happiness, Communitarian, Eschatology

$\mathrm{E}$ very art and every inquiry, and similarly every action and pursuit, is thought to aim at some good; and for this reason the good has rightly been declared to be that at which all things aim. But a certain difference is found among the ends..."2 These are the opening words of Aristotle's Nicomachean Ethics. They raise more questions than answers. For example: What is the end of all ends? How do we learn about the "final" end? And what if our personal ends are manipulated by some "soft" or "hard" power, that is, through deception or coercion? How do we know that the ends we pursue are our own ends and not someone else's? Whom may we trust? Who takes the "burden" of responsibility and gives us criteria for proper aims and proper means? Who is the "mediator" between us and the desired, between what "is" and what "ought" to be: Is it our senses? Or our reason? Science and technology? Some authority? Or our inner feelings?

Aristotle says that there must be some chief good which we desire for its own sake. ${ }^{3}$ For those who do not believe in the afterlife, this good could be the prolongation of a happy life. For those who believe in God and eternal life, the good could be God - the source of life. ${ }^{4}$ But we are not used to being conscious about the highest good. Our attention is often diverted to small things and achievements that promise peace and happiness. We exist like seeds sown among thorns: we know about the final good, but the cares of the

1. Paper presented on November 1st, 2019, for the Colloquium "Christian Theology After Christendom.” Organized by McGill University's School of Religious Studies and University of Toronto's Emmanuel College. For a broader discussion of many of the themes presented in this paper, see Tsoncho Tsonchev, Person and Communion: The Political Theology of Nikolai Berdyaev (PhD diss. McGill University, 2021), https://escholarship.mcgill.ca/concern/theses/cf95jh19g.

2. Aristotle, Nicomachean Ethics, trans. W.D. Ross (Raleigh, NC: Alex Catalogue, 2000), Book 1.1. (1094a), http://classics.mit.edu/Aristotle/nicomachaen.1.i.html.

3. Aristotle, Nicomachean Ethics, Book 1.2 (1094a, 20).

4. "When I seek for you, my God," Augustine says, "my quest is for the happy life. I will seek you that 'my soul may live' (Isa. 55:3), for my body derives life from my soul, and my soul derives life from you." See Augustine, Confessions, trans. E. B. Pusey (New York: Collier Books, 1961), Book 10, Ch. 20, https://www.gutenberg.org/files/3296/3296-h/3296-h.htm. 
world and the deceitfulness of riches choke this knowledge, and it proves "unfruitful" (as is reiterated in Matt. 13: 22). ${ }^{5}$

The highest good is the universal good, and as such, seems to be related to politics, whose aim is the achievement of the common good. According to Aristotle the function of politics is legislation. Politics, or government, legislates "what we should do and what to avoid"6 so that we achieve happiness. Happiness, Aristotle argues, is this universal, common good to which we all strive. Happiness is what we choose for itself and never for the sake of something else. There is nothing that we want beyond happiness. Happiness, in Aristotelian view, is "something final and self-sufficient, and is the end of action.",

But there is an alternative view. According to the Gospel of John, Christ says "If you continue in my word [...] you will know the truth and the truth will set you free" (John 8: 31-32). It seems that the final end, according to the Christian view, is not happiness, not even virtue, but freedom. Christianity does not aim at temporal happiness. Its truth mediates the achievement of freedom. And here, we face the question that everyone would ask at least once in his or her life: Would I prefer freedom, or rather, do I want happiness?

The world pursues happiness. But what comes first? Freedom or happiness? Is happiness a means for the achievement of freedom? Or it is freedom that makes us happy? The immediate answer is that freedom without happiness is nothing, while happiness without freedom is something. Therefore, happiness must be a greater good than freedom and thus, the truth of Christianity is a lesser truth for a lesser good. Christian freedom is not a lack of suffering. Happiness, however, is. Also, freedom does not guarantee the "daily bread," material comfort and security. It does not guarantee social success, honor, or power. On the contrary, Christian freedom is service, often deprivation. It is spiritual rather than material. Freedom is detachment from the world, while happiness is the strongest possible attachment to it. The Christian truth teaches us to eat spiritual bread when we are hungry, to have faith when we live in a mechanical world, and to serve what we do not see instead of ruling over what we can see. Christian truth and freedom seem the absolute opposite to worldly happiness and wisdom.

\section{Dostoyevsky's Theocracy}

Dostoyevsky explored the antinomic nature of freedom and happiness in many of his writings, most prominently in the "Story of the Grand Inquisitor" in his book Brothers Karamazov (1879-1880). ${ }^{8}$ One of the amazing things one may notice while reading the story is that the word "Christ," or "Savior," is never used. The story is about Christ (and the anti-Christ), but the name "Christ" is never mentioned. In this story, Jesus is just "He" or the "Prisoner." The Truth that makes us free is called "the Prisoner." In this story, Christ, the Word, is silent. The only words He utters are: "Talita cumi! - Arise, maiden!" when He resurrects a dead girl, before being arrested. Dostoyevsky depicts Christ as a silent listener to the long plea of an accuser, the Inquisitor, an old man who has taken on the burden of making humanity happy and peaceful.

The "Story of the Grand Inquisitor" is a dystopian vision of a theocratic regime where church and state rule united for the happiness of humankind. In it, Christ comes in a human form a day after a hundred heretics were burned in the presence of the king, royal court, knights, beautiful ladies, and the entire popu-

5. All references and quotes taken from the Bible are from the New International Version, 2011.

6. Aristotle, Nicomachean Ethics, Book 1.3. (1094b).

7. Aristotle, Nicomachean Ethics, Book 1.7. (1097b, 20).

8. Fyodor Dostoyevsky, The Brothers Karamazov: With an Introduction by Malcolm V. Jones, trans. Richard Pevear, and Larissa Volokhonsky (New York: Alfred A. Knopf, 1992). 
lation. He is immediately recognized by the crowd and people gather around Him shouting "Hosanna!" His radiant presence and the healings he performs attract the attention of the theocratic authority. He is arrested and thrown in jail. People do not oppose. In the night, the Grand Inquisitor visits the Prisoner. He asks Him, "Why did you come here, to interfere and make things difficult for us?" Not waiting for an answer, he continues: "Well, I do not know who You really are, nor do I want to know whether You are really He or just a likeness of Him, but no later than tomorrow I shall pronounce You the wickedest of all heretics." And what is Christ's error? It is that he brings actual freedom. For hundreds of years "we were pestered by that notion of freedom," the Inquisitor says, "but in the end we succeeded in getting rid of it." Now, the Inquisitor notes, the people even think that they are free. Actual freedom is nothing compared to the perception of freedom that brings happiness and peace. "It is only now," he continues, "that it has become possible, for the first time, to think of men's happiness. Man is a rebel by nature and how can a rebel be happy?"

Jesus listens to these words silently. He never promised happiness, nor did He ask for obedience. His coming was not about happiness, but about freedom. In fact, Satan was the one who tempted Christ in the desert with the notion of happiness. Christian freedom, in the view of the Grand Inquisitor, is a "vague" and irresponsible "promise," a temptation for weak creatures like human beings. He says, "[T]here has never been anything more difficult for man and for human society to bear than freedom." Men, the Inquisitor says, want the stones turned into bread, they want a miracle, and a leader whom to follow. There are three forces on earth that can make man happy: "miracle, mystery, and authority." Man would follow anyone who offers bread, miracle, and leadership. But Christ rejected all these. And this, in the Inquisitor's view, was his fault. There is no such thing, he says, as crime, there is no sin either, "there are only hungry people." "Feed us first, then ask for virtue; enslave us, but feed us!" - this is the reality of human life, and Christ did not respond to it.

So, "we have corrected your work," the Inquisitor says, "and have now founded it on miracle, mystery, and authority. And men rejoice at being led like cattle again, with the terrible gift of freedom that brought them to such suffering removed from them." "Listen then," he tells Christ. "We are not with You, we are with him - and that is our secret, our mystery! [...] And we shall devise a plan for universal happiness." "Him," whom "they" follow, is the "Anti-Christ." The Inquisitor calls Satan the "mighty spirit," which Jesus rejected in the desert. Had Christ accepted Caesar's purple, the last temptation, He would have founded a "universal empire and given men everlasting peace." "For who can rule men if not one who holds both their consciences and their bread?"

The Inquisitor is the image of this earthly authority that combines in itself the spiritual and temporal power, that keeps everything under its control: human bodies, thoughts, dreams, and conscience. There is peace under this authority because all are innocent like children. No one decides, only "he" - the Grand Inquisitor and his associates. The Grand Inquisitor is people's conscience. We will "pacify" mankind, the Inquisitor says, making people "like children, will control their feelings and emotions, and will know their 'secrets,' they will tell us everything and we shall solve all their problems, and they will trust our solutions completely." Millions of beings will be happy with the exception of those who are called to rule, for only they, the keepers of the secret, will know the "lie" and the truth of whom they really serve. Millions will die peacefully, the Inquisitor says, but "beyond the grave they will find nothing but death." To all this, Christ says nothing. He gets up, approaches the "tormented," in the words of Dostoyevsky, old man who "loves mankind" "stubbornly," and "gently" kisses his "bloodless lips." "The kiss glows in his heart... But the old man sticks to his old idea." The silence of Christ leaves his accuser, and the readers of this story, free to choose. So that in our freedom, he and we may decide between freedom and happiness. 
Dostoyevsky's Grand Inquisitor has a sequel in Evgenyi Zamyatin's fiction $W e^{9}$ - a novel written in the 1920s in the dystopian world of Soviet Russia. In this book, Christ is completely absent. He has left the world and has not returned. The Inquisitor, however, is still present, now in the form of a mystical figure named the Great Benefactor, a man who rules a highly advanced technological society. If Dostoyevsky's story was about theocracy, Zamyatin's novel is about what we may call-logocracy, or rule of reason.

\section{Zamyatin's Logocracy}

Now, can we say that reason is related to freedom? Human reason depends on external data, on logic, and on mimetic analogy. Properly speaking, human reason does not create, it classifies, re-orders the natural order according to a rational idea or natural need. Reason, in its essence, is not freedom. In its internal workings, it follows its own absolute logic, while in its external actions it deals with natural laws. The only freedom that reason could bring to humanity is to liberate it from the terror of natural forces, and to allow us a level of dominance over nature - for example, freedom from physical pain, from hunger, from natural cataclysms, etc. All this external freedom that comes from the dominion over nature, however, has nothing to do with the inner freedom, that is, the freedom to believe in eternal life, the freedom to selfsacrifice, and the freedom to admit the existence of a reality that can neither be thought nor experienced in the present human condition. Such a reality, for reason, can only be death. For the rational being, death is something that can be neither imagined nor experienced. Human reason, as a mimetic phenomenon, cannot imagine eternal life, because there is no eternal life in the natural world. Therefore, reason, as Kant suggests, must admit its limits and focus on the business of earthly happiness and not on the idea of eternal life. And here is the paradox: happiness without eternity is meaningless. All rational substitutes of meaning are shallow, and the only thing that can make human life meaningful is eternal life, a concept that contradicts rational explanation. Moreover, the only way for the achievement of absolute happiness and freedom what the Stoics, for example, passionately pursued but never fully understood ${ }^{10}$ - is through this irrational idea of the existence of eternal life that is neither seen nor experienced in the present human condition.

Having said all this, Evgenyi Zamyatin's dystopia that paints a completely rational world with a complete earthly happiness is the natural sequel of Dostoyevsky's story of the Grand Inquisitor. If you remember, the Inquisitor said, "Millions will die peacefully, but beyond the grave, they will find nothing but death." Their happiness is a lie, and it can be nothing else. And because it is a lie, it cannot be truth. Even if their happiness had the semblance of a virtuous life, it would still be a lie, because human fulfilment is impossible without eternal life. Good does not come from evil, as truth does not come from lies. The happiness of the completely rational society that does not permit anything but data and logic, order and control, is not happiness, but death - it is the dead nature of a stone pushed to the extreme. The stone follows

9. Evgenyi Zamyatin, We, trans. Natasha Randall (New York: Random House, 2007).

10. The Stoics prepared, as it were, the ground for the expansion of the Christian ethos among the more speculative minds of antiquity. But as Paul Tillich observes in The Courage to Be, the "victory of the Christian Church pushed Stoicism into an obscurity from which it emerged only in the beginning of the modern period." "It is remarkable," Tillich says, "that among the emperors it was not the willful tyrants of the Nero type or the fanatical reactionaries of the Julian type that were a serious danger to Christianity but the righteous Stoics of the type of Marcus Aurelius." See Paul Tillich, The Courage to $B e$ (Yale University Press: New Heaven \& London, 2000), 10. The limit of the Stoic moral philosophy was human reason and nature; Stoicism never dared to seriously question the sources of reason and they deeply seated in it: faith in eternity. This feature of human reason that is contradictory to reason itself was discovered by Christianity and was most succinctly expressed in the famous words of Anselm: "Faith seeking understanding." Anselm's motto implies that there is a difference between intellect and faith, but also a relation, and in this relation the intellect comes second to faith. See Anselm of Canterbury, trans. and ed. Jasper Hopkins, and Herbert Richardson (Toronto: E. Mellen Press, 1974). 
its natural course - it is "happy" in its predictable gravitational trajectory. ${ }^{11}$ The freedom of a stone is no greater than the freedom of a logical sequence. The peace of a stone is no lesser than the peace of a mathematical formula.

We must admit that historically humanity progresses towards "happiness" without eternal life and regresses from freedom and faith in eternal life. We should also admit the importance of numbers in our daily life, where we live in a sea of bits and digits that form our perceptions, "predict" our feelings, read our minds, measure our "worth," and control our machines. The put-in-practice "digit" is the latest product of rational human progress towards happiness. It is not a coincidence that the main character of Zamyatin's novel "We" has no name, like all other characters. He is a number, a code; he is called D-503. The only being with a name in this novel is the Grand Benefactor. The Grand Benefactor, like the Grand Inquisitor, is the force behind all numbers. He is the power that brings happiness through the destruction of freedom. At the very beginning of the novel, D-503, a man who celebrates the rational system of the organized society, in which he lives and for which the works to advance, says that the aim of the Grand Benefactor is to "subjugate to the grateful yoke of reason" all beings in the universe, all who live in the "primitive state of freedom." "If they will not understand that we are bringing them a mathematically faultless happiness," D-503 says, "[then] our duty will be to force them to be happy. But before we take up arms, we shall try the power of words."

D-503 lives in a "United State." In his peaceful world there are no nations and states, but only one United State with only one ruler - the Great Benefactor, who cares for the peace of all. In this state, there are no persons. People are numbers that fit seamlessly in the universal matrix of digital order. These numbers, these people, are neither individuals nor persons, they are We. They are neither free nor autonomous, they have no right to think beyond the limits of the system nor do they have the right to feel. Any feeling they have must be suppressed and replaced with a pure logic that corresponds to the logic of the universal matrix of peace and happiness. There is such unanimity among the human numbers of this world that they even "intersect their thoughts." There is no privacy, all live in houses with walls of glass, all have uniforms, and designated roles, and everything is regulated. They are sedentary people. Or as D503 states, "It is dear that the history of mankind [...] is a history of the transition from nomadic forms to more sedentary ones. Does it not follow that the most sedentary form of life, ours, is at the same time the most perfect one?" Now, taking into account our own experience of COVID 19-lockdowns and limits to movement, we must wait to be convinced that staying at home is better and safer than going out. We must be convinced that this is so for our own good and for the good of all that may die. Death is real for us, the rational people, thus we find happiness and safety in social distancing and sedentary life, a life behind screens of digits through which we connect, digits that read our minds, thoughts and feelings, collecting data for future happiness and safety.

It will be impossible to recount Zamyatin's book in detail as it is beyond the scope of this paper. But I will say that both Zamyatin and Dostoyevsky describe totalitarian societies as built on the idea of happiness. And I will also bring to your attention the proposition that happiness, or utilitarianism, is not contradictory to totalitarianism and slavery. And that slavery is not in opposition to reason. Reason has great "reasons" to defend the value and worth of slavery. We should not forget that Aristotle did not reject slavery. Slavery was normal practice up until the appearance of Christianity, which then gave us the idea of freedom of belief and human dignity. Namely, the freedom to believe is what made slavery bearable un-

11. Cf. Seneca's On the Happy Life, Ch. 5 and 8 in Lucius Annaeus Seneca, Seneca's Morals Abstracted: In Three Parts: I. of Benefits, II. of a Happy Life, Anger, and Clemency, III. a Miscellany of Epistles, trans. Roger L. L'Estrange (London: Printed by T. N. for Henry Brome, 1679). 
der the yoke of human authority, natural necessity, and rational argument. It is in this freedom of faith only, I think, we can find true meaning.

Before we move on to our next topic of discussion, I ask, how can one be happy in this temporal life, even if one is virtuous, if one witnesses the suffering of one's brethren? Or how can one be happy if one knows that God was crucified? He either must believe that Christ has not died, and rejoice, ${ }^{12}$ or lament like Nietzsche, who said "God is dead. God remains dead. And we have killed him. How shall we comfort ourselves, the murderers of all murderers?" 13 Thus, let us choose one answer to the questions, asked at the beginning:

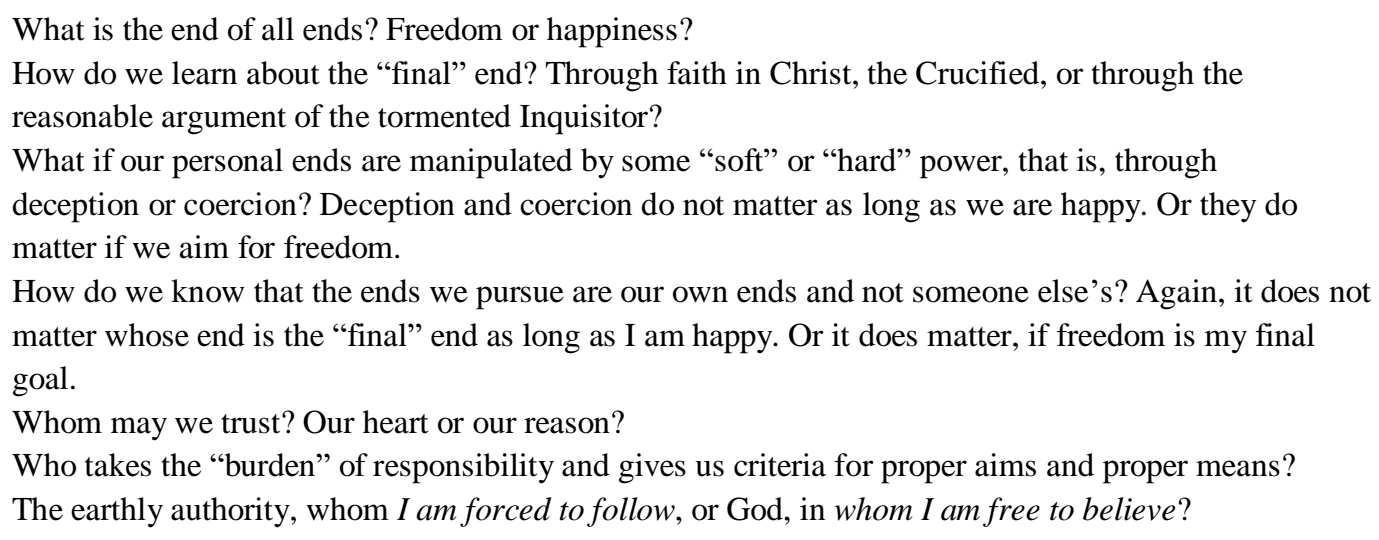

Who is the "mediator" between us and the desired, between what "is" and what "ought" to be: Is it our physical senses which tell us that we cannot live without material bread? Or is it our reason that rejects the idea of eternal life but embraces the worth of virtuous life? Or is it science and technology that come to replace the "miracles"? Or is it some earthly authority that has taken on the burden to make us happy? Or is it that inner feeling that tells us that life is meaningless without Christ: the way, the truth, and the life itself? (John 14: 6).

\section{Berdyaev's Sobornost}

We face two alternatives: either happiness incarnated in a socio-political organism that masks the ugliness of natural finitude or freedom incarnated in a suffering man who reveals the beauty of divine eternity; either materialism and all embracing numeric and technological economism or freedom, where one plus one is three; either uniformity or unity; either totality or plurality; either matter or Spirit; either power or faith; either state or church.

12. And this joy could be described as "happiness," or as Augustine states, "That is authentic happy life, to set one's joy on You (God), grounded in You and caused by You [...] Those who think that the happy life is found elsewhere, pursue another joy and not the true one." Augustine's argument about happiness is not very different from the argument advanced here. He says that the "happy life is joy based on the truth," that is, on God, "who is the truth." According to Augustine, human intellect is incapable of reaching the truth without the help of some innate memory rooted in being human. People, Augustine says, would have "no love for [truth] unless there were some knowledge of it in their memory." Everyone loves the truth naturally. This is proved by the fact that no one wants to be deceived as no one wants to be unhappy. Yet, when the truth reveals man's sin, man starts to "hate" the truth and so rejects both his happiness and freedom. "While human mind lies open to the truth," Augustine notes that the "truth remains hidden from it." The human mind does not want to admit its own "deceitfulness." Augustine, Confessions, Book 5, Ch. 22, 23.

13. Friedrich Nietzsche, The Gay Science, trans. Thomas Common, Paul V. Cohn, and Maude Dominica Petre (Mineola, New York: Dover Publications, 2020), 103-104 (Section 125). 
The Russian philosopher Nikolai Berdyaev, who was an admirer of Dostoyevsky and a contemporary of Zamyatin, had a good sense of the conflict between freedom and temporal happiness, between Spirit and matter, church and state. For him, as for Dostoyevsky and Zamyatin, the state was not an incarnation of the Spirit and the Good. It could be a sign or a trace of the workings of the Spirit in history, but it was neither a means for the achievement of happiness nor an end to human life, nor for that matter the Spirit (or Freedom) incarnated. The late Hegel would not agree with such an interpretation. In Hegel's view, the state was the "Divine Idea as it exists on earth." 14 These words would be blasphemy for Berdyaev. Hegel expressed another thought that is reminiscent of the Inquisitor's logic and sophistry. In his lectures on the philosophy of history, Hegel states that under the influence of Christianity only the German nations were first able to "attain consciousness that man, as man, is free: that is the freedom of Spirit, which constitutes its existence." ${ }^{\prime 15}$ These assertions reflected Hegel's philosophical understanding of the "Unity of Spirit" in history. The Spirit for Hegel was a "totality," the totality of freedom that tends towards itself. The state was also a kind of totality, composed of different and reconciled "wills." "Truth," Hegel believed, "is the Unity of the universal and subjective will; and the Universal is to be found in the state, in its laws, its universal and rational arrangements." He argued that the state is the "reality of freedom": the "objective unity" of the "idea of freedom," that is the Universal Spirit, and the "means" for its realization, that is, subjective will. Hegel believed that freedom is historically realized in society and the state. Berdyaev did not. For Berdyaev, the "state" and "society" were not, to use Hegel's words, "the very conditions" for the realization of freedom. Berdyaev had great respect for the Hegelian philosophy of history, but he did not accept most of its conclusions.

To summarize in bold strokes, Hegel believed in the existence of a World Spirit, which was essentially a result of its own activity, and which constantly overcomes and transcends "unreflected existence" (or the unconscious). The Spirit constantly actualizes the potency of everything still partial individuals, nations, civilizations - into a "self-comprehending totality." Whereas in Berdyaev's writings we do not have any positive idea of totality. Rather, we have sobornost, communion, and in this communion, self-comprehension is just the inexpressible and deep awareness of the existence of the "other" (Thou) in the very self of the "I." Here, we should note that in Berdyaev's philosophy the "other" as a person is not dissolved into the I but fulfilled in the We that contains the I and the Thou in their individual uniqueness and worth. For Berdyaev, the Spirit is a Person and Energy. While for Hegel, the Spirit is Energy, but not a person. Personalism does not play a role in Hegel's thought, but "individualism" does. The individual "ego," for Hegel, is just "self-centered" action, or will, that blindly and unconsciously follows the higher purpose of Providence. The individual ego is dialectically reconciled with other individual egos within the "Freedom of the Spirit." The ought ${ }^{16}$ of the individual ego does not really matter for the ought of the Spirit, because only the ought of the Spirit represents the "is" of all "oughts." The individual ego finds its fulfilment in the ideal state, and the ideal state, on the other hand, finds its ideal constitution in the realization of the individual ego within the state. This is so because, as Hegel optimistically believes, the "state is well constituted and internally powerful when the private interest of its citizens is one with the common interest of the state; when the one finds its gratification and realization wi-

14. G. W. F. Hegel, The Philosophy of History, trans. J. Sibree (New York: Dover Publications, 1956), see for this and for the quotations that follow the Introduction, 1-103.

15. Hegel, The Philosophy of History, 1-103.

16. The "ought" here is intended to mean/refer to duty. 
th the other." 17 In Berdyaev's thought there is no state that could ever "gratify" the needs, the wills, and the dreams of all of its citizens. Berdyaev is much more of a realist than the late Hegel, and in his philosophy, often described as "idealism," the state could not represent a positive example and reflection of the unity of the Spirit. In his political theology, in his philosophy of history, and his eschatology, all having the elements of unity (sobornost) and personhood, the Hegelian idea of the state as a possible analogy and expression of the unity of the Spirit is non-existent.

In The Realm of Spirit and the Realm of Caesar, Berdyaev says that "collectivism is not sobornost (соборность), but simply being together (sbornost; сборность)." 18 Collectivism has a "mechanicalrational character." 19 Secular ideologies and regimes, the "ideologies of happiness," if we may call them so, were aimed at and created collectivism, but none of them fully reflected the ideal of Christian personalistic communitarianism. They created mechanical gatherings of men and not true communities. The reason for this was that in them the individual person did not actually matter. Сбор (sbor) in Russian and in Slavonic languages means "collection," a mechanical accumulation. The word is used for the goals of arithmetic, taxation, financing, etc. The sbor between one and one is always two. The word "sbor" has for its root the Old Church Slavonic term coбор (съборь, subor), which means "meeting," "council,"” "assembly." Meeting, council, assembly is a gathering of persons, and not of numbers or quantities. The personal element has a primary function in the word sobor, while in sbor it may have only secondary meaning. Only persons can come together in a council; the result of the persons' council is never the mechanical quantity, rather it is the qualitative change. So, in contrast to the sbor, in the sobor one plus one equals three, and not two. The sobor of two persons is not "two," but "we," 20 and it is so because this sobor

17. In Hegel's philosophy of religion, it is not only the coincidence of the universal with the individual that represents the fulfilment of freedom in the state. There should also be a degree of correspondence between people's concept of God and the actuality of God. For example, in his lectures on the relationship of religion to the state, Hegel says that "A people which has a bad concept of God also has a bad state, a bad government, and bad laws." This is so because the state is an "actualization" of the Spirit. A national conscience that has not reached a sufficient understanding of the divine freedom is practically incapable of creating a just and well-ordered state. "The state is the true mode of actuality," Hegel argues, "in it, the true ethical will attains actuality and the spirit lives in its true form [...] The laws are the development of the concept of freedom, and this concept, which thereby reflects itself in existence, has its foundation and truth in the concept of freedom as understood in religion." Hegel and Berdyaev's political theologies have some common characteristics, especially in relation to the correspondence between political regimes and ideologies and the Christian communitarian and personalistic ideals. But the most obvious difference between them is in Hegel's rather optimistic treatment of the state. The state for Hegel seems to take the form of an "embodied" divinity. This view naturally leads to totalitarian, "pagan" conclusions and Berdyaev understood this. See G.W.F. Hegel, "The Relationship of Religion to the State (1831)," in Hegel: Political Writings, Cambridge Texts in the History of Political Thought, ed. Laurence Winant Dickey and H. B Nisbet (Cambridge: Cambridge University Press, 2004) 225-226.

18. Nikolaĭ Berdyaev, The Realm of Spirit and the Realm of Caesar, (London: V. Gollancz, 1952), 122. In the original Russian, the quote is as follows, "Коллективизм не соборность, а сборность. Он носит механически-рациональный характер,” in Н.А.Бердяев. 1995. Царство Духа и Царство Кесаря. М.: Республика, С.332

19. Berdyaev, The Realm of Spirit, 122, Бердяев, 332.

20. Сf. В.В. Колесов, “Жизнь происходит от слова...” [Life Originates from the Word...] (“Златоуст”) "Sobornost,” the historian of Russian language V. Kolesov writes, "is not at all 'collection (sbornost) of elements,' but namely this wholeness that defines all particularities of the Russian character. 'This is the secret life of the Spirit. 'We' in the sobornost is not a collectivity. Collectivism is not sobornost, but sbornost..." Cf. Н. А. Бердяев, Алексей Степанович Хомяков. Миросозериание Достоевского. Константин Леонтьев. (Собрание сочинений, 1997) [N. A. Berdyaev, Alexei Stepanovich Khomiakov. Dostoyevsky's Wordview. Konstantin Leontioev, ed. N. A. Struve (Paris: YMCA-Press; M.: Christian Publishing House, 1997)] C.165: “По учению славянофилов, голос земли Русской не может быть услышан и узнан по арифметическому подсчету голосов, это - голос соборный, а не сборный, органический, а не механический." Translation: "According to the Slavophil teaching, the voice of the Russian land cannot be heard or known from an arithmetical adding up of voices, this - is a sobornyi voice of community, not some sbornyi voice of an assembly roll-call, it is organic, and not something mechanical." See Nikolaĭ Berdyaev, Aleksêi Stepanovich Khomyakov (frsj Publi- 
is not something abstract, it is not a collection of things, it is not arithmetical, it is not even "naturally necessary." 21 It would be interesting to inquire how, in history, the word sobor, which signified the gathering of persons (that resulted in an authentic "We," not Zamyatin's "We") was drained of its spiritual meaning and transformed into the word sbor, used for expressing the mechanical collection of numbers and things. If one asked what the difference between sbor and sobor is, one of the possible answers could be: in the former (sbor) one plus one is two, while in the latter (sobor) One plus One is Three. Or, if one asked what the difference between collectivity and communion is, the possible answer could be: the former is mechanical-rational, the latter is free-spiritual. In the sbor, we have the solitude of the dead abstraction (the logic of the Grand Inquisitor and Benefactor), in sobornost, we have the "communion" of the living experience (the freedom in Christ).

"The problem of personality in relation to society," Berdyaev says, "is essentially a problem of metaphysics and existential philosophy." 22 "Intuition," he adds, "is the foundation of communion, the faculty of being able to identify oneself with all things." 23 This intuitive and living (existential) identification makes the sobornost something very different from the mechanical collectivity of human sbor. Communion, Berdyaev argues, cannot be described just as a society. In society and the state, we have a sbor of individuals. The person is secondary. In communion, the "community becomes a part of the personality and endows it with a special quality." In society, "personality is merely a part of the community." If the whole dominates over the part, and if the part is just a fragment of the whole, and not the opposite - i.e., the very center and reason for the existence of the whole - the part finds itself violated, alienated, and abandoned. Berdyaev reminds us that all populist ideologies - Fascism, Nazism, Communism, and Eurasianism - looked at the person as a part of a whole. But we belong and feel together, according to Berdyaev, only so far as this world, this country, this family, this person, this Christ, is part of us. They (this world, country, family, person, and Christ) are, because I am, if I am not, they are not too. They have no meaning at all if I do not exist. It is I who has the God-like freedom to give them meaning. I "name" them according to the meaning I find in them. And, on the other hand, I, myself, have no meaning at all, if I do not have them in me. If I reject them, then I reject myself. If they reject me, or kill me, then they reject and kill part of themselves, a part so significant that it will make them nothing (every time a man dies a whole universe dies with him). There is no communion in a "society" of individuals indifferent or aggressive to each other, in a gathering of strangers having their own survival and gratification (happiness) as the sole reason for existence. In the communion, the person affirms his "supreme value," ${ }^{24}$ while affirming the value of all that are in him. Thus, "the only way to abolish the exploitation of man by man," Berdyaev writes, "is to confront the Ego with the Thou" 25 - a confrontation that happens in the person itself.

Society, for Berdyaev, is always an "association," the association that we find, for example, in the anarcho-individualistic logic of Max Stirner. ${ }^{26}$ Yet, it is the state, not society, that is the very anti-thesis of

cations, ASK, 2017), 141-142. All Russian translations are those of the author. It is important to note that the translations of the Russian offered attempt to stay as close as possible to the original meaning and also to maintain the original sentence structure, which may seem odd in English, but I wish to present to the reader Berdyaev's intended nuances.

21. "Formalism and juridical guarantees are necessary only in relationships of conquerors and conquered, but are unnecessary there where the state - is organic, is of the people as regarding its source." See Berdyaev, Aleksêi Stepanovich Khomyakov, 131.

22. Nikolaĭ Berdyaev and George Reavey, Solitude and Society (London: G. Bles, 1938), 180.

23. Berdyaev and Reavey, Solitude and Society, 180.

24. Berdyaev and Reavey, Solitude and Society, 181.

25. Berdyaev and Reavey, Solitude and Society, 184.

26. See Max Stirner, The Ego and His Own, trans. Steven T. Byington (New York: Boni and Liveright, 1918). 
communion. Stirner was against the state, but he failed to comprehend the meaning of communion. Society relies on communication, the state not necessarily. However, communication is not quite a communion. Communion is something more than communication and social interaction, it is participation. "The significance of communion as a goal of human life," Berdyaev says, "is essentially religious. Communion involves participation, interpenetration." 27 "The interpenetration of the Ego and the Thou is consummated in God." ${ }^{28}$ In communion, the "antitheses" of "the one and the multiple" are resolved; the division between the particular and universal is eliminated.

The problem with all forms of collectivism, of sbornost, is that they try to transfer the "moral and existential center" of existence from the concrete person towards a "quasi-reality, which is above and beyond man." ${ }^{29}$ But this, in fact, is impossible. There is no "above" and "beyond" the concrete man. Above and beyond is a lack of suffering, of feeling, of love. "The capacity of suffering," Berdyaev notes, perhaps following suit with Dostoyevsky, "is the mark of truly primary reality." It is so because suffering is what defines us as living beings and not happiness. And suffering is much more related to freedom than to selfsufficient happiness which is blind to the suffering of the Other. In this sense, we may venture to say, that the tormented "Grand Inquisitor" is more of a man than his system of rule leads us to believe, he is more of a person than his impersonal and rational ideology. His suffering, or his personhood, deserves the "kiss of Christ." As a tormented man, the Inquisitor is still a man, and as such he is still open to change, or to communion. "The kiss glows in his heart..." Finally, Berdyaev believes that full communion, which is also the absolute of reality, is possible only through God. ${ }^{30}$ Christ in us (Emmanuel), ${ }^{31}$ and we in him, and with him, the entire world, and life. Sobornost, he concludes, is "the mysterious life of the Spirit."

\section{The Communion of Life}

As we have seen, both freedom and happiness are related to the question of life and death. Thus, I ask, as believers in eternal life, should we stay indifferent to death? Or, if we are rational positivists, should we just forget about death and focus entirely on the achievement of a happy life? In Phaedo, Socrates advises that we should always sing incantations about the immortality of the soul, ${ }^{32}$ which will help us to overcome the fear of death, and possibly make us happy. Death is an end, and as an end, as we have seen, it can be either the end of all ends or the sublime means for the achievement of eternal life, the final end of existence itself.

27. Berdyaev and Reavey, Solitude and Society, 188.

28. Berdyaev and Reavey, Solitude and Society, 188.

29. Berdyaev, The Realm of Spirit, 118.

30. Berdyaev, The Realm of Spirit, 120.

31. Cf. Douglas John Hall, Lighten Our Darkness: Towards an Indigenous Theology of the Cross (Philadelphia: Westminster, 1976), 118. The "Theology of the cross," Hall says, "declares God is with you - Emmanuel. He is alongside with you in your suffering. He is in the darkest place of your dark night. You do not have to look for him in the sky, beyond the stars, in infinite light, in glory unimaginable. He is incarnate. That means he has been crucified."

32. "No sensible man would insist that these things are as I have described them, but I think it is fitting for a man to risk the belief - for the risk is a noble one - that this, or something like this, is true about our souls and their dwelling places, since the soul is evidently immortal, and a man should repeat this to himself as if it were an incantation... That is the reason why a man should be of good cheer about his own soul, if during life he has ignored the pleasures of the body and its ornamentation as of no concern to him and doing him more harm than good, but has seriously concerned himself with the pleasures of learning, and adorned his soul not with alien but with its own ornaments, namely, moderation, righteousness, courage, freedom and truth, and in that state awaits his journey to the underworld" (Plato, Phaedo, trans. G.M.A. Grube [Indianapolis: Hackett Publishing Company, 1977], 114d-115a, italics mine). 
"Death," Berdyaev says, "is the most profound and significant fact of life [...] Life in this world has meaning just because there is death [...] the meaning is bound up with the end." 33 This argument brings us to the meaning of the idea of personhood and communion in Berdyaev's thought. Berdyaev is sometimes described as a Christian "universalist," that is, a believer in "universal salvation." ${ }^{34}$ According to some authors, the idea of universal salvation is not supported by Scripture, it is rather a new phenomenon, ${ }^{35}$ and, as Berdyaev argued, a specific feature of the Russian religious soul and thought. The idea of universal salvation had a particular resonance with Russian thinkers. Although tolerated, it never became a part of the official teaching of the Russian Orthodox Church.

Berdyaev's personalism and communitarianism naturally lead to the idea of universal salvation. But it would be hasty to classify him, without qualification, as a "universalist." ${ }^{36}$ Here we face a persistent problem regarding Berdyaev's philosophy - that it does not easily fit into positive descriptions, that it has an "apophatic" quality. So, it is perhaps more accurate to describe him as "anti-particularist" (or, if I use D. B. Hart's term, anti-“infernalist") rather than a universalist. Berdyaev's personalism and communitarianism do not support the idea of personal election or of final damnation. But as we will see, they also do not comply with the logic of a "mechanical" universal salvation. And the reason for this last observation is his concept of freedom, of Ungrund (non-being), which puts some limits, not so much on God, but on man. For Berdyaev, man participates in his salvation. Man was not created to fall and wait for God's mercy and grace. The idea of Ungrund, of abysmal freedom and darkness, does not permit us to believe with certainty and comfort that man is willing and capable of receiving the gift of salvation. It is so because, according to Berdyaev, neither God nor man knows what man will do with salvation at hand. In Berdyaev's thought (but not in Böhme's), abysmal darkness is not in God, as it is not fully in man. Man, the first Adam, chose death (nothingness), and now, in his sin, he still prefers death. But in Christ, the God-man chooses life. "For as by a man came death, by a man also came the resurrection of the dead" (1 Cor. 15:21). "For as in Adam all die, so also in Christ all will be made alive" (1 Cor. 15:21). Does this "all" literally mean "all", or only those who are "in Christ"? And what does it mean to be in Christ? Berdyaev would not accept the simple, "partisan" answer to these questions. In fact, he would not give an answer at all. Like the silent Christ, in Dostoyevsky's story, he leaves us with the hope that man, even in the form of a Grand Inquisitor, will wish for life in Christ. That man will prefer the "passion" of Christ and not his "reason," and will become a "lifegiving spirit" (1 Cor. 15:45), a person, not just a "living soul" (1 Cor. 15:45) or individual. Thus, Berdyaev

33. Nikolaĭ Berdyaev, The Destiny of Man (London: G. Bles, 1959), 317.

34. On the history of the idea of universal salvation, see Michael McClymond, The Devil's Redemption: A New History and Interpretation of Christian Universalism (Grand Rapids, MI: Baker Academic, 2018). In this book, McClymond rightly points out Berdyaev's influence on the early Hans Urs von Balthasar. His interpretation of Berdyaev's universalism is correct, especially his emphasis on Berdyaev's criticism of fear of hell and punishment as a means to control man's free will. McClymond quotes perhaps Berdyaev's most important claim concerning hell, which will be discussed here: "in a certain sense man has a moral right to hell - the right freely to prefer hell to heaven." He also observes that Berdyaev was less concerned with the justification of universalism than Bulgakov, having a specific "yes-no" (or "dialectical") position on hell. As he says, "Berdyaev neither rightfully affirms nor decisively denies the doctrine of hell" (McClymond, The Devil's Redemption, 705-712).

35. Or an old-new phenomenon as David Bentley Hart recently argued in a much-discussed book, That All Shall be Saved: Heaven, Hell, and Universal Salvation. According to Hart, the early Christians were universalists. It is only after the fourth century, that the idea of universal salvation became more "exotic," mostly because of the growing influence of Western (Latin) interpretation of Scripture. Universalism, Hart argues, gained currency once again in the nineteenth century, and that's why it could be now described as a "new-old" idea. See David Bentley Hart, That All Shall be Saved: Heaven, Hell, and Universal Salvation (New Haven Connecticut: Yale University Press, 2019).

36. As Michael McClymond implies. For McClymond, Bulgakov is the only one among the influential Silver Age Russian philosophers who "affirmed 'universalism' in a more or less straightforward way." See McClymond, The Devil's Redemption, 743-744. 
brings to our attention not only the death, but also the resurrection of man as a creative spirit, as a person that by their own will, faith, and confession, is "steadfast, immovable, abounding in the work of the Lord," "knowing" that their "toil is not in vain in the Lord" (1 Cor. 15:58).

In Berdyaev, we do not have a "divine comedy." On the contrary, he often speaks about the "tragedy" of man. This "tragedy" is caused by the gift of freedom; it means that man should suffer for his salvation, that man should bear the cross like Christ, his Lord, that he is destined to exclaim, before his resurrection, "Eli, Eli, lema sabachthani?" ("My God, my God, why have you forsaken me?" Matt. 27:46). It is so because Christ himself asks "Will you indeed drink My cup?" (Matt. 20:22). Freedom, Berdyaev says, is in "its essence the principle of tragedy, of tragic dualism, and of the antithesis inherent in primal freedom which alone makes possible such a tragic destiny." 37

Berdyaev directs our attention to the fact that death is in our life. He says that "our existence is full of death and dying. Life is perpetual dying, experiencing the end of everything." 38 Consciousness about the existence of death is consciousness about the existence of life, but also a temptation. Our life is constantly torn off, it is full of separations and severances, and we are blinded by the darkness of the perpetual end of communion. Death and dying is separation. Sin is separation. Death is evil because it makes life look temporal; it tempts us to believe that there is no God, no eternity, no communion. It gives us only one perspective - the perspective of space and time, of the temporal and material. In such a perspective there is no place for "I am who I am" or for "I am who I will be." It is nothingness. And it is a great defeat for the human spirit to succumb under the temptation of the perpetual end and lose the memory of the single beginning. ${ }^{39}$ But death, Berdyaev believes, is self-defeating. Through the death of Christ, we came to believe that there is no death, that the eternal communion of life is real, and the darkness of nothingness is truly nothingness. Eternity, Berdyaev is convinced, is reached "only by passing through death." Only through the death of Christ was life asserted and glorified. The old Adam broke communion with God and continues to break it through "every evil passion" 40 - through his pride, greed, ambition, fear, envy, and hatred. Death as sin tends toward non-being, it is a denial of eternity - it is a great temptation to believe that everything is ultimately nothing since everything ends in nothingness and perdition. Death tries to reject everything but itself. The negation of everything negates everything but itself. But this is our sinful interpretation of death. The "comedy" in all this "tragedy" is in the simple fact that the absolute negation is a negation of the absolute negation as well. Again, death is self-defeating. Death puts an end to sin, to negation, and with the end of sin life begins. Death also heals.

Who would truly prefer the hell of the sinful nature, of constant disunion and pain, the bitterness, the torture of anger and war, the weakness of a perishable body? No one in their "right mind"; no one who knows what they are "doing" (Luke 23:34). Yet, many keep their faith in the senseless crucifixion of life saying, "Aren't you the Messiah? Save yourself and us!" But others say, "Do you not even fear God? For are you not under the same judgment? We are punished justly, for we are receiving what our actions deserve. But this man has done nothing wrong." They may not believe in the Messiah, but they believe in justice, in life, even on the cross they know that the innocent should not die; they assert life over death. These people, while still on the cross, will hear the voice of the Son of Man, "Truly I tell you, today you will be with Me in Paradise." (Luke 23:39-43) This is the "comedy of death": just confess the right of the innocent and the drama ends, you enter the realm of God. "The moral paradox of life and death," Berdyaev says, "can be ex-

37. Nikolaĭ Berdyaev, The Meaning of History, trans. George Reavey (Cleveland: Meridian Books, 1962$), 77$.

38. Berdyaev, The Destiny of Man, 319.

39. Or "principle." See Vladimir Solovyov, Lectures on Godmanhood, intro. Peter P. Zouboff (Dennis Dobson, 1948).

40. Berdyaev, The Destiny of Man, 320. 
pressed by a moral imperative: treat the living as though they were dying and the dead as though they are alive." 41 This paradox asks one thing only: to have mercy for the sake of Truth and Life (James 2:13).

There is confusion in the idea that life conquers death through constant birth. Berdyaev notes that this is the "naturalistic view." 42 Birth as a kind of "savior" from death is an illusion. Birth saves the "race," the human "generation," but not the person. It is the person who should be saved, not the generation. If the person is sacrificed for the sake of the generation, then, there is no hope for anyone in this generation, nor does its existence have any meaning. The naturalistic view, Berdyaev argues, is close to Hegelian idealism. As noted, in Hegel and in German metaphysics in general, there is "no place for personality." 43 The person is merely a function of the world-spirit or idea. ${ }^{44}$ In Hegel, Berdyaev says, there is no sense of the tragedy of death; there is no genuine sense of human drama. The abstractions of logic and metaphysics are "cold," indifferent. "Death is a tragedy only when there is acute awareness of personality." 45 The human person is born for eternal life, and it is a scandal and drama to face the reality of death in cold blood. Naturalism regards man as born from a father and mother and does not accept or care for the person born in God for the communion of life. "Fichte and Hegel," Berdyaev says, "have nothing to say about personal human immortality." Personality is sacrificed for the Idea. Without personalism, true communion is impossible; from this it follows that the self-realizing Unity of the World-Spirit is a self-serving Leviathan. No part should be lost in the freedom of Spirit. Man is not a "means," he is a center and part of everything. ${ }^{46}$ There is no self-contained Spirit as there is no self-contained person. The person is united in life "with God, with other persons, and with the cosmos." ${ }^{\prime 47}$ Any general idea of progress or evolution is absolutely impersonal, and for that reason "natural" and "mechanical." For Berdyaev Christianity has discovered the value of personality, of the uniqueness of each human being, and the possibility of its preservation. The Greeks, he argues, did not believe in the immortality of man and the Jews were conscious of the immortality of their race but not of persons. ${ }^{48}$

"Having lost the sense of immortal and eternal life," Berdyaev notes that "man has freed himself from the painful problem of hell and thrown off the burden of responsibility." 49 On the one hand, the belief in hell enslaves man, keeping him in the grip of fear; on the other hand, it imposes on him a sense of responsibility. But neither the enslavement to fear, nor the responsible action that comes from fear is good. Berdyaev does not defend the conventional idea of the existence of hell, but he also does not approve the lack of responsibility found in modern hedonism and atheism. He thinks that the idea of hell has Persian and Manichean roots and that later interpretations of the gospel disregarded the context and metaphoric meaning of the Biblical Hebrew concept of "Sheol." He notes that the idea of hell is ontologically connected with freedom and personality, and not with justice and retribution. ${ }^{50} \mathrm{He}$ says that hell is "admissible" in the sense that man, in his freedom, may want it and prefer it to paradise. Perhaps, he says, a man may feel better

41. Berdyaev, The Destiny of Man, 321. Cf. Augustine, The City of God, trans. Marcus Dods (Edinburgh: T. \& T. Clark, 1958), Book 13, Ch. 10. https://www.gutenberg.org/files/45304/45304-h/45304-h.htm. "Whether we should not speak of the life of mortals as a death rather than a life [...]"

42. Berdyaev, The Destiny of Man, 323.

43. Berdyaev, The Destiny of Man, 324.

44. Berdyaev, The Destiny of Man, 324.

45. Berdyaev, The Destiny of Man, 324.

46. Berdyaev, The Destiny of Man, 325.

47. Berdyaev, The Destiny of Man, 325.

48. Berdyaev, The Destiny of Man, 326.

49. Berdyaev, The Destiny of Man, 338.

50. Berdyaev, The Destiny of Man, 239. 
in hell than in heaven. ${ }^{51}$ Berdyaev understands hell as the lack of communion, as total isolation. "Eternal perdition," he contends, "means that personality remains self-contained, indissoluble and absolutely isolated." ${ }^{, 2} \mathrm{God}$, according to him, does not send a man to hell; man puts himself there. "From the point of view of God, there cannot be any hell." The experience of hell is a human experience - it means "complete self-centredness" and "self-absorption." ${ }^{53}$ In hell are those, he says, who remain in time, those who prefer their sin even on the cross of life. These are the people who "do not want to pass into eternity." "Wh "When Origen said that Christ will remain on the cross," Berdyaev says, "so long as a single creature remains in hell, he expressed an eternal truth." ${ }^{, 5}$ Thus, the thief prefers to sleep in the phantasm of death. He does not care for the innocent, he wants salvation, but by his free will he desires union neither with man nor with God. This is a tragedy and drama.

There is another tragedy. It is a tragedy to stay cold, indifferent to the fate of those who do not know what they are doing (Luke 23:34). Who actually knows what they are doing in this earthly, sinful life, in which everything is seen through a "partial mirror" (1 Cor. 13:12)? Who is this person who knows everything, even the heart of man and its "story"? "I may experience the torments of hell and believe that I deserve them," Berdyaev says, "But it is impossible to admit hell for others or be reconciled to it... It is hard to understand the psychology of pious Christians who calmly accept the fact that their neighbours, friends, and relatives will perhaps be doomed." 56

This lack of "understanding" may sound familiar. Many people today would say that they feel the same way as Berdyaev when thinking about eternal damnation. But we should not forget that Berdyaev expressed these views in a time of great crimes, of poverty, war, and hatred, that he lost friends in concentration camps and prisons, and was forced to leave his homeland, which he loved so much. In such a context, only a Christian with a great heart would have the power to say that there is no eternal damnation, in the face of the "evil" that surrounds him. Or, perhaps, this experience of excess evil led him to unconditional love and mercy. Why should I desire a greater evil, hell, even for the sake of justice? Who should be saved in a world full of sinners? Should one constantly struggle to seek the salvation of others, instead of raising the scepter of judgement and condemnation? Indeed, this, is what Berdyaev proposes:

\footnotetext{
If people were morally more sensitive, they would direct the whole of their moral will and spirit towards delivering from the torments of hell every being they have ever met in life. [...] The true moral change is a change of attitude towards the 'wicked' and the doomed [...] This implies that I cannot seek salvation individually, by my solitary self, and make my way into the Kingdom of God relying on my own merits. ${ }^{57}$
}

Solitary salvation is also a break from communion. In the Great Commandment (Matt. 22:36-40), we are three, not two: God, I, and my neighbour. I do not join a circle of "elect," as we often do here in the earthly life and leave my poor brethren alone to endure in the pain of his sins. I would rather stay here with him, on the cross, and wait for him to join me. Christ did not leave us. Neither would I leave him.

51. Berdyaev, The Destiny of Man, 340.

52. Berdyaev, The Destiny of Man, 340.

53. Berdyaev, The Destiny of Man, 341.

54. Berdyaev, The Destiny of Man, 342. Here Berdyaev argues that Origen believes that Christ will stay on the cross, that is, will be with us, among us, in every generation, until the last sinner is corrected - simply until the hell of this life and the other is overcome.

55. Berdyaev, The Destiny of Man, 347.

56. Berdyaev, The Destiny of Man, 350.

57. Berdyaev, The Destiny of Man, 351. 
Berdyaev is convinced that there is no "personal paradise," that there is no bliss in isolation. He imagines that finally, Cain will join Abel, not in spite of his sin, but because of God. ${ }^{58}$ Berdyaev understands that hell is "the state of the soul powerless to come out of itself," which is in a state of absolute selfcenteredness, incapable of love. ${ }^{59}$ "Hell creates and organizes the separation of the soul from God, from God's world and from other men." It is the "absence of any action of God upon the soul." It is I who imposes this hell unto myself. The truth is, Berdyaev says, that the "coming of Christ is the salvation from the hell which man prepares for himself." 60

Hell is an illusion, a non-being, and as such, it is the kingdom of the Devil, "the realm of dark meonic freedom." Here we return to the perplexing idea of Ungrund, the "meonic freedom." Berdyaev argues that "victory over meonic freedom is impossible for God" because this freedom was not created by Him and because it is "rooted in non-being." He says that it is impossible also for man, "since man has become the slave of that dark freedom and is not free in his freedom." But victory is still possible, and it is possible through the "God-man Christ Who descends into the abysmal darkness of meonic freedom and in Whom there is perfect union and interaction between human and divine." Thus, "Christ alone can conquer the horror of hell as a manifestation of the creature's freedom [...] The salvation from hell is open to all in

Christ the Savior." ${ }^{\prime 61}$ For Berdyaev, this is a personal task, and here is a hope and faith that can be described as hope for "universal salvation." In this salvation the "prince of this world" is left behind as an illusion, and the communion of all persons is fully achieved. He writes, "Not only must all the dead be saved from death and raised for life again, but all must be saved and liberated from hell." This is a task for the now, for this moment; and this is "the last and final demand of ethics." This ethical demand proclaims: "Direct all the power of your spirit to freeing everyone from hell. Do not build up hell with your will and actions, but do your utmost to destroy it." ${ }^{62}$ The moral will, not moral theory, must be directed in the first place towards universal salvation. ${ }^{63}$

Salvation is not the return to an original paradisiacal state. The paradise of the "end" is different from the paradise of the "beginning." The final paradise includes conscious freedom and knowledge about divine Humanity. The old paradise did not have such knowledge. Berdyaev says that "Once man has entered the path of discriminating between good and evil, knowledge as such is not evil." "Knowledge has evil for its object, but itself is not evil. And through knowledge man's creative vocation is realized." Paradise is not the triumph of good and justice. Justice and good are already triumphant. Rather, it is a "theosis, a deification of the creature." ${ }^{\prime 64}$ It is also the fullness of communion. "True heavenly bliss is impossible for me if I isolate myself from the world-whole and care about myself only. [...] The separation of man from man and of man from cosmos is the result of Original sin." Man separates from God and man falls into isolation from the communion of life. Salvation, however, is the "return of man with man and with the cosmos through reunion with God." 65 "Hence, there can be no individual salvation or salvation of the elect." "My salvation," Berdyaev says, "is bound up with that not only of other men but also of animals, plants, minerals, of every blade of grass - all must be transfigured and brought into the Kingdom of God. And this

58. Berdyaev, The Destiny of Man, 351.

59. Berdyaev, The Destiny of Man, 351.

60. Berdyaev, The Destiny of Man, 352.

61. Berdyaev, The Destiny of Man, 356.

62. Berdyaev, The Destiny of Man, 357.

63. Berdyaev, The Destiny of Man, 357.

64. Berdyaev, The Destiny of Man, 364.

65. Berdyaev, The Destiny of Man, 372. 
depends upon my creative efforts." ${ }^{\prime 66}$ Man, as we have said, is a center of a universe: "To affirm the supreme value of personality does not mean to be concerned with personal salvation; it means to recognize that man has the highest creative vocation in the life of the world." There are two kinds of good: one that distinguishes right from wrong, the knowledge that we received from the forbidden fruit, and the other that "does not judge or make valuations but radiates light." The second kind of good is Love, it is above good itself. Love is not to judge "evil," but to suffer it, to experience it, and to overcome it in the communion of life. ${ }^{67}$

66. Berdyaev, The Destiny of Man, 373.

67. Berdyaev, The Destiny of Man, 374. 


\section{Bibliography}

Anselm of Canterbury. Translated and edited by Jasper Hopkins and Herbert Richardson. Toronto: E. Mellen Press, 1974.

Aristotle. Nicomachean Ethics. Translated by W. D. Ross. Raleigh, NC: Alex Catalogue, 2000. http://classics.mit.edu/Aristotle/nicomachaen.1.i.html

Augustine. The City of God. Translated by Marcus Dods. Edinburgh: T \& T Clark, 1958. https://www.gutenberg.org/files/45304/45304-h/45304-h.htm.

—. Confessions. Translated by E. B. Pusey. New York: Collier Books, 1961. https://www.gutenberg.org/files/3296/3296-h/3296-h.htm.

Berdyaev, Nikolaǐ and George Reavey. Solitude and Society. London: G. Bles, 1938.

Berdyaev, Nikolă. Aleksêi Stepanovich Khomyakov. frsj Publications, ASK, 2017.

—. Alexei Stepanovich Khomiakov. Dostoyevsky's Wordview. Konstantin Leontioev. Edited by N. A. Struve. Paris: YMCA-Press; M.: Christian Publishing House, 1997.

—. The Destiny of Man. London: G. Bles, 1959.

—. The Meaning of History. Translated by George Reavey. Cleveland: Meridian Books, 1962.

—. The Realm of Spirit and the Realm of Caesar. London: V. Gollancz, 1952.

Dostoyevsky, Fyodor. The Brothers Karamazov: With an Introduction by Malcolm V. Jones. Translated by Richard Pevear and Larissa Volokhonsky. New York: Alfred A. Knopf, 1992.

Hall, Douglas John. Lighten Our Darkness: Towards an Indigenous Theology of the Cross. Philadelphia: Westminster, 1976.

Hart, David Bentley. That All Shall be Saved: Heaven, Hell, and Universal Salvation. New Haven Connecticut: Yale University Press, 2019.

Hegel, G. W. F. The Philosophy of History. Translated by J. Sibree. New York: Dover Publications, 1956.

—. "The Relationship of Religion to the State (1831)." In Hegel: Political Writings, Cambridge Texts in the History of Political Thought, edited by Laurence Winant Dickey and H. B Nisbet, 225-233. Cambridge: Cambridge University Press, 2004.

McClymond, Michael. The Devil's Redemption: A New History and Interpretation of Christian 
Universalism. Grand Rapids, MI: Baker Academic, 2018.

Nietzsche, Friedrich. The Gay Science. Translated by Thomas Common, Paul V. Cohn, and Maude Dominica Petre. Mineola, New York: Dover Publications, 2020.

Plato. Phaedo. Translated by G. M. A. Grube. Indianapolis: Hackett Publishing Company, 1977.

Seneca, Lucius Annaeus. Seneca's Morals Abstracted: In Three Parts: I. of Benefits, II. of a Happy Life, Anger, and Clemency, III. a Miscellany of Epistles. Translated by Roger L. L'Estrange. London: Printed by T. N. for Henry Brome, 1679.

Solovyov, Vladimir. Lectures on Godmanhood. Introduction by Peter P. Zouboff. Dennis Dobson, 1948.

Stirner, Max. The Ego and His Own. Translated by Steven T. Byington. New York: Boni and Liveright, 1918.

The Holy Bible, New International Version. Grand Rapids: Zondervan Publishing House, 2011.

Tillich, Paul. The Courage to Be. Yale University Press: New Heaven \& London, 2000.

Tsonchev, Tsoncho. Person and Communion: the Political Theology of Nikolai Berdyaev. PhD dissertation, McGill University, 2021. https://escholarship.mcgill.ca/concern/theses/cf95jh19g.

Zamyatin, Evgenyi. We. Translated by Natasha Randall. New York: Random House, 2007. 